\title{
Physical Fruit Traits, Nutritional Composition, and Seed Oil Fatty Acids Profiling in the Main Date Palm (Phoenix dactylifera L.) Varieties Grown in Morocco
}

\author{
Mohamed Ibourki (D), ${ }^{1}$ Fadma Azouguigh, ${ }^{1}$ Si Mohamed Jadouali, ${ }^{1}$ El Hassan Sakar (D), \\ Laila Bijla $\left(\mathbb{D},{ }^{1}\right.$ Khalid Majourhat, ${ }^{1,3}$ Said Gharby $\mathbb{C}^{1},{ }^{1}$ and Abdelatif Laknifli $\mathbb{C}^{1}$ \\ ${ }^{1}$ Laboratory Biotechnology, Materials and Environment (LBME), Faculty Polydisciplinary of Taroudant, University Ibn Zohr, \\ Agadir, Morocco \\ ${ }^{2}$ Department of Biology, Faculty of Sciences of Tetuan, Abdelmalek Essaâdi University, Mhannech II, Tetuan 93002, Morocco \\ ${ }^{3}$ Laboratory of Engineering Sciences and Energy Management, National School of Applied Sciences, Ibn Zohr University, Agadir, \\ Morocco
}

Correspondence should be addressed to El Hassan Sakar; sakar.statistics@gmail.com and Said Gharby; s.gharby@yahoo.fr

Received 18 April 2021; Revised 12 September 2021; Accepted 5 October 2021; Published 14 October 2021

Academic Editor: Marcio Carocho

Copyright ( 2021 Mohamed Ibourki et al. This is an open access article distributed under the Creative Commons Attribution License, which permits unrestricted use, distribution, and reproduction in any medium, provided the original work is properly cited.

\begin{abstract}
We investigated fruit physical traits and nutritional value in both seed and flesh in eight Moroccan date palm varieties. The greatest values of weight for whole fruit, flesh, seed, and flesh percentage were found in "Boufgous," "Agondari," and "Bouskri." These two later varieties displayed also their superiority with respect to proximate composition. For fruit flesh, proximate composition, energy value, and reducing capacity ranged as follows: proteins (1.60-3.53\%), moisture (5.31-17.31\%), ash (2.08-2.50\%), lipids (0.32-1.09\%), carbohydrates (76.69-90.18\%), energy value $(338.30-385.89 \mathrm{kcal} / 100 \mathrm{~g})$, and reducing capacity $(100.14-1607.12 \mathrm{mg}$ GAE/100 g). Corresponding values in seeds were as follows: proteins (3.20-5.00\%), moisture (1.42-4.14\%), ash (1.14-1.50\%), lipids (6.30-7.40\%), carbohydrates (83.39-85.55\%), energy value (417.06-429.51 kcal/100 g), and reducing capacity (1427.71-6843.84 mg GAE/100 g dry weight). Among all minerals (K, Ca, Mg, B, Fe, Cu, Mn, Na, and Zn) found in both fruit parts, $\mathrm{K}$ had the highest records for both flesh $(12047 \mathrm{mg} / \mathrm{kg})$ and seed $(6127.6 \mathrm{mg} / \mathrm{kg})$, followed by $\mathrm{Mg}$ and Ca. Seeds lipidic fraction was dominated by monounsaturated fatty acid C18:1 (47.5\%), followed by saturated fatty acids mostly C12:0 (18.0\%), C14: 0 (10.5\%), and C16: 0 (10.6\%) and finally polyunsaturated fatty acid C18:2 (8.8\%). It could be concluded that investigated varieties presented a great importance from a nutritional point of view, and seeds could present important opportunities of valorization.
\end{abstract}

\section{Introduction}

Date palm (Phoenix dactylifera L.) is a very important species in arid and semiarid areas [1,2]. It plays an important role from economic, social, and ecological standpoints $[3,4]$. The date palm is renowned due to its delicious fruits, reported to have distinct nutritional and medicinal properties [5]. It is an important source of sugars, nutrients, and antioxidants $[6,7]$. From an agronomic perspective, the fruit development period in date palm lasts about 200 days from pollination to full ripening, known as Tamar stage [8]. Three distinct phases can be distinguished during ripening, during which fruits undergo substantial metabolomic changes, as highlighted by Diboun et al. [9]. According to these authors, during the first phase, fruits are enriched in regulatory hormones, amines and polyamines, energy production, tannins, sucrose, and antioxidants. The second phase is characterized by ongoing phenylpropanoid secondary metabolism, gene expression, and phospholipid metabolism and a late phase with marked sugar dehydration activity and degradation reactions leading to increased synthesis of volatile compounds. 
From a pomological standpoint, date palm fruit consists of a fleshy pericarp surrounding a seed [10]. Owing to its nutritional richness, the fleshy pericarp is consumed fresh, dry, or under various processed forms such as dough and jam [11]. However, seeds are considered a waste product generated by date palm industries [12] and are used mainly for animal feed [13]. Seeds can also be processed into foods such as noncaffeinated coffee and in cosmetic products [1].

In Morocco, the date palm is cultivated in several areas generally located on the southern side of the Atlas Mountains along the wadis [3]. Most of this heritage is concentrated mainly in the valleys of Drâa and Ziz and the Bani area in Tata region [3]. According to the latest FAOSTAT's release, date production in Morocco increased from 101,351 tons in 2010 to 129,562 tons [14]. Seeds account for about 7 to $18 \%$ of the total weight of dates $[15,16]$. The Moroccan date seeds production was estimated at about 9,069 tons in 2017, which offers opportunities for valorization in favor of national economy and local population.

Compositional studies on Moroccan date palm varieties are scarce, especially those devoted to characterizing both flesh and seeds, hence the originality of this work. Herein, we aimed at (i) investigating the nutritional composition (proteins content, lipids, carbohydrates, polyphenols, and mineral elements) and related energy value in the two parts of the date fruit (flesh and seeds) in eight Moroccan varieties to establish the criteria for the characterization and identification of each variety and (ii) determining seeds oil content and its fatty acids composition.

\section{Material and Methods}

2.1. Plant Material, Study Area, and Sampling. This study was carried out on date palm fruits belonging to eight Moroccan varieties from three sites in southeastern Morocco. "Agondari," "Ismmarti," "Sair," and "Matrouh" were sampled from Ouarzazate $\left(30^{\circ} 55^{\prime} 08^{\prime \prime} \mathrm{N}, 6^{\circ} 53^{\prime} 36^{\prime \prime} \mathrm{W}\right.$; 1113 m.a.s.l.), while "Boufkouss" and "Jihel" were harvested from Errachidia $\left(31^{\circ} 55^{\prime} 55^{\prime \prime} \mathrm{N}, 4^{\circ} 25^{\prime} 28^{\prime \prime} \mathrm{W} ; 1039\right.$ m.a.s.l.), and "Amouch" and "Bouskri" were collected from Tata $\left(29^{\circ} 44^{\prime} 34^{\prime \prime} \mathrm{N}, 7^{\circ} 58^{\prime} 21^{\prime \prime} \mathrm{W} ; 670\right.$ m.a.s.l.). Sites were selected based on their important cultivated acreage, commercial production, and similar agronomical managements practiced by local growers. In the above-mentioned sites, orchards are conducted under rainfed conditions and undergo similar agronomical practices without any fertilizer or phytosanitary treatment.

The three sites are located in southeastern Morocco. Tata is under a warm Mediterranean climate with dry summer; it has an annual rainfall of $353.8 \mathrm{~mm}$ with an average temperature of $19.2^{\circ} \mathrm{C}$. The two remaining sites are under desert climate (according to the Köppen-Geiger classification) with a continental influence. Errachidia and Ouarzazate receive about $127 \mathrm{~mm}$ and $112.2 \mathrm{~mm}$ of annual precipitations with average temperatures of $19.2^{\circ} \mathrm{C}$ and $19.6^{\circ} \mathrm{C}$, respectively, following Moroccan Department of National Meteorology.

For fruit sampling, from each variety, three healthy trees of similar age were used for fruit harvesting [17, 18]. At Tamar stage, from each tree, about $1.5 \mathrm{~kg}$ of fruits was harvested around trees canopy following the four compass directions. Immediately after harvesting, samples were brought to the lab, where dates were pitted manually, and the fleshes were dried at $80^{\circ} \mathrm{C}$ to facilitate grinding. Fleshes and seeds were then crushed and stored in dark bottles at $4^{\circ} \mathrm{C}$ until use.

All solvents used were of analytical or HPLC grade and were purchased from VWR international (Darmstadt, Germany).

2.2. Physical Fruit Traits Measurement. Before starting measurements, impurities were removed, such as unripe or damaged fruits, as well as dirt and dust. To determine physical fruit traits of interest, fifty date fruits were randomly taken from each variety. For each individual fruit, the whole fruit weight (FW) and the corresponding flesh weight (fW) and seed weight (SW) were measured using a precision electronic balance with a sensitivity of $0.001 \mathrm{~g}$. The percentages of flesh (fP, \%) and seed (SP, \%) were also calculated.

\subsection{Proximate Composition and Energy Value}

2.3.1. Moisture Content (MC). Briefly, $5 \mathrm{~g}$ of fruit flesh powder samples was placed in a ventilated oven (Precision Scientific Co., USA) at $103^{\circ} \mathrm{C}$ until reaching a constant weight. MC was calculated according to the following equation [19]:

$$
\mathrm{MC}(\%)=\frac{P 2-P 3}{P 2-P 1} \times 100,
$$

where $P 1$ is the weight of container with lid, $P 2$ represents the weight of container with lid and sample before drying, and $P 3$ corresponds to the weight of container with lid and sample after drying.

2.3.2. Ash Content (AC). The samples ( $5 \mathrm{~g})$ of the pulp were dried at $80^{\circ} \mathrm{C}$ in an oven until they reached a constant weight. Then all flesh and seed samples were finely crushed. Later, one gram of dried powder was calcinated in the furnace for 4 hours at $500^{\circ} \mathrm{C}$.

2.3.3. Protein Content (PC). PC was quantified based on the measurement of nitrogen using combustion by a LECO FP628 (LECO Corp., MI, USA) Proteins Analyzer, based on the Dumas method following the AOAC method 992.15 [20]. A factor of 6.25 was then used to convert measured nitrogen to PC expressed in percent.

2.3.4. Oil Content (OC). Twenty fully ripe fruits from the eight varieties were subjected to Soxhlet extraction to determine OC. Seeds were separated and oven-dried at $60^{\circ} \mathrm{C}$ for 3 hours and then finely ground. The powders of seeds and fleshes were Soxhlet-extracted (Büchi, Switzerland) with $\mathrm{n}$-hexane for 8 hours. The solvent was partly removed in a rotary vacuum evaporator (R-200, Büchi, Zurich, Switzerland) at $40^{\circ} \mathrm{C}$, and the rest of the solvent was removed under 
stream of nitrogen to a constant weight to determine the oil content gravimetrically. The oils were filtered and stored in dark glass bottles at $4^{\circ} \mathrm{C}$ until analysis.

\subsubsection{Total Carbohydrates Content (CC) and Energy Value} $(E V)$. CC for each fruit part (flesh and seed) in the eight date varieties was calculated by subtracting the sum of the other components (proteins, moisture, ash, and oil) using the following formula given in the work of Besbes et al. [12]:

$$
\begin{aligned}
\text { Carbohydrates }(C C, \%)= & 100 \%-(\% \mathrm{PC}+\% \mathrm{MC} \\
& +\% \mathrm{AC}+\% \mathrm{OC}) .
\end{aligned}
$$

EV (expressed as kcal/100 g dry basis) was computed from values of MC, AC, PC, OC, and CC using the following equation described by Crisan and Sands [21]:

$$
\begin{aligned}
\text { Energy value }\left(\mathrm{eV}, \frac{\mathrm{kcal}}{100 \mathrm{~g}}\right)= & (2.62 \times \% \mathrm{PC})+(8.37 \times \% \mathrm{OC}) \\
& +4.2 \times \% \mathrm{CC}
\end{aligned}
$$

2.4. Dietary Elements Determination. Nine dietary elements ( $\mathrm{K}, \mathrm{Ca}, \mathrm{Mg}, \mathrm{B}, \mathrm{Fe}, \mathrm{Cu}, \mathrm{Zn}, \mathrm{Mn}$, and $\mathrm{Na}$ ) were determined on the obtained ash in fleshes and seeds according to Mohammed et al. [22]. For the mineralization assay, $0.25 \mathrm{~g}$ of sample was mixed with $10 \mathrm{~mL}$ of $\mathrm{HNO}_{3} 69.5 \%$ and $8 \mathrm{~mL}$ of $\mathrm{H}_{2} \mathrm{O}_{2} 35 \%$. The mixture was quickly brought to $140^{\circ} \mathrm{C}$ for $4 \mathrm{~h}$ (close to dryness). Immediately after cooling, $1 \mathrm{~mL}$ of $\mathrm{HNO}_{3}$ $1 \%$ was added to the mixture and the final volume was completed to $25 \mathrm{~mL}$ with deionized water.

Dietary element content was measured using an ICPAES spectrometer (Jobin Yvon, Ultima 2) equipped with an axial viewed plasma. Operating conditions were the following: power $1.15-1.2 \mathrm{~kW}$, plasma flow gas $12-14 \mathrm{~L} / \mathrm{min}$, auxiliary gas flow $1.5 \mathrm{~L} / \mathrm{min}$, and nebulizer gas flow $0.2 \mathrm{~L}$ / $\min$.

2.5. Fatty Acids Composition in Seeds Oil. The fatty acids were esterified by boiling under reflux for 10 minutes. A mixture of $1 \mathrm{~g}$ of oil, $10 \mathrm{~mL}$ of methanol, and $0.4 \mathrm{~mL}$ of $2 \mathrm{~N}$ potassium hydroxide was prepared in methanol. After cooling at room temperature, $2 \mathrm{~mL}$ of $\mathrm{n}$-hexane was added to the mixture and washed with distilled water. The hexane layer containing fatty acid methyl esters (FAMEs) was collected and analyzed. The fatty acid composition was determined as their corresponding methyl esters by gas chromatography (Agilent6890) coupled with a flame ionization detector (GC-FID). The capillary column CP-Wax $52 \mathrm{CB}(30 \mathrm{~m} \times 250 \mu \mathrm{m}$ i.d., $0.25 \mu \mathrm{m}$ film thickness) was used. The carrier gas was helium, and the total gas flow rate was $1 \mathrm{~mL} / \mathrm{min}$. The initial oven temperature was $170^{\circ} \mathrm{C}$, the final temperature $230^{\circ} \mathrm{C}$, and the temperature gradient was $4^{\circ} \mathrm{C} / \mathrm{min}$. Injector and detector temperature were set at $220^{\circ} \mathrm{C}$. The injection volume of the samples was $2 \mu \mathrm{L}$ in a split mode (split ratio $1: 50$ ). The results were expressed as the relative percentage of the area of each fatty acid peak.

2.6. Reducing Capacity (RC). $10 \mathrm{~g}$ of flesh or seed powder samples was extracted with $30 \mathrm{~mL}$ of methanol-water $(80$ : $20, \mathrm{v} / \mathrm{v})$; for $24 \mathrm{~h}$ at room temperature, the mixture was then filtered, and the filtrate was diluted $(1: 100)$. Subsequently, $0.5 \mathrm{~mL}$ of sample solution extract was mixed with $2.5 \mathrm{~mL}$ of Folin-Ciocalteu reagent in water $(1: 10)$, and then $4 \mathrm{~mL}$ of $\mathrm{Na}_{2} \mathrm{CO}_{3}(7.5 \% \mathrm{w} / \mathrm{v})$ was added. The mixture was then incubated in a water bath at $45^{\circ} \mathrm{C}$ for $30 \mathrm{~min}$ and the absorbance at $765 \mathrm{~nm}$ was measured. The calibration curve was prepared using gallic acid under the same conditions. RC was expressed as mg of Gallic Acid Equivalent (GAE) per $100 \mathrm{~g}$ of fruit (flesh or seeds) dry weight $[23,24]$.

2.7. Statistical Analysis. The analyses of variance (ANOVA) were performed and quantitative differences among mean values were assessed by the general linear procedure followed by Tukey's test. Statistical analyses were performed using the SPSS package version 23 (IBM, Armonk, NY, USA). Results were expressed as means \pm standard deviations (SD). Differences were considered significant at a probability level of 5\%. Principal component analysis (PCA) was performed to discriminate among varieties on one hand and between fruit parts on the other hand using STATGRAPHICS package version XVII (Statpoint Technologies, Inc., Virginia, USA).

\section{Results and Discussion}

3.1. Physical Fruit Traits. Along with chemical composition, physical fruit traits are very important as they define fruit quality and consumer acceptance [18]. Date fruits can be sorted based on their morphological traits [4]. Results of physical fruit traits are summarized in Table 1. There were significant variations among the studied varieties for FW, fW, SW, fP, and SP. The average FW in the investigated varieties was $7.43 \mathrm{~g}$, with only four varieties weighing less than this average. FW ranged from $14.03 \pm 1.68 \mathrm{~g}$ in "Boufgous" to $3.26 \pm 0.31 \mathrm{~g}$ in "Sair." FW of "Boufgous" was significantly higher than those reported in the literature for eighteen Moroccan varieties such as "Aguellid" (7.78 g), "Ahardane" (8.39 g), "Bouijjou" (9.16 g), and "Bourhare" (9.75 g) [25].

The fP values ranged from $74.43 \pm 3.30 \%$ ("Bouskri") to $89.70 \pm 1.04 \%$ ("Boufgous"). Several Moroccan varieties, such as "Majhoul" and "Bourhare" have a higher fP (>90\%) than the studied varieties [25]. Moreover, Acourene et al. [26] reported a higher value of fP (91.23\%) for "Boufgous" grown in Algerian oases. Such variations could be ascribed to pedoclimatic differences under which date varieties are grown, as explained by Taouda et al. [4]. Higher SW values were observed in "Agondari" $(1.44 \pm 0.18 \mathrm{~g})$, "Ismmarti" $(1.40 \pm 0.35 \mathrm{~g})$, and "Boufgous" $(1.39 \pm 0.18 \mathrm{~g})$, while lower records of SW (<1 g) were found in "Sair," "Matrouh," and "Jihel". SP (Table 1) ranged from $10.14 \pm 1.51 \%$ ("Boufgous") to $25.30 \pm 3.40 \%$ ("Bouskri"). Our results regarding SP were comparable to those reported by Bouhlali et al. [15] 
TABLE 1: Mean values of physical fruits traits, namely, fruit weight (FW), flesh weight (fW), seed weight (SW), flesh percent (fP), and seed percent (SP), for the studied date palm varieties. All values are means \pm standard deviation. In each column, values followed by the same letter are not significantly different at $5 \%$ as a probability level.

\begin{tabular}{lccccc}
\hline Variety & FW $(\mathrm{g})$ & $\mathrm{fW}(\mathrm{g})$ & $\mathrm{SW}(\mathrm{g})$ & $\mathrm{fP}(\%)$ & SP $(\%)$ \\
\hline "Agondari" & $6.93 \pm 0.75^{\mathrm{bc}}$ & $5.42 \pm 0.74^{\mathrm{cd}}$ & $1.44 \pm 0.18^{\mathrm{a}}$ & $78.21 \pm 3.40^{\mathrm{bc}}$ & $21.01 \pm 3.10^{\mathrm{ab}}$ \\
"Amouch" & $8.54 \pm 1.07^{\mathrm{bc}}$ & $7.23 \pm 0.58^{\mathrm{bc}}$ & $1.20 \pm 0.15^{\mathrm{ab}}$ & $84.72 \pm 7.90^{\mathrm{ab}}$ & $14.32 \pm 2.92^{\mathrm{bc}}$ \\
"Boufgous" & $14.03 \pm 1.68^{\mathrm{a}}$ & $12.58 \pm 1.57^{\mathrm{a}}$ & $1.39 \pm 0.18^{\mathrm{a}}$ & $89.70 \pm 1.04^{\mathrm{a}}$ & $10.14 \pm 1.51^{\mathrm{d}}$ \\
"Bouskri" & $5.11 \pm 0.55^{\mathrm{cd}}$ & $3.80 \pm 0.19^{\mathrm{de}}$ & $1.29 \pm 0.19^{\mathrm{ab}}$ & $74.43 \pm 3.30^{\mathrm{a}}$ & $25.30 \pm 3.40^{\mathrm{a}}$ \\
"Ismmarti" & $9.60 \pm 1.27^{\mathrm{b}}$ & $8.09 \pm 0.95^{\mathrm{b}}$ & $1.40 \pm 0.35^{\mathrm{a}}$ & $84.31 \pm 2.90^{\mathrm{ab}}$ & $14.60 \pm 2.32^{\mathrm{cd}}$ \\
"Jihel" & $7.91 \pm 1.41^{\mathrm{bc}}$ & $6.91 \pm 1.46^{\mathrm{bc}}$ & $0.93 \pm 0.09^{\mathrm{ab}}$ & $87.40 \pm 9.80^{\mathrm{ab}}$ & $12.08 \pm 2.11^{\mathrm{d}}$ \\
"Matrouh" & $4.02 \pm 0.50^{\mathrm{de}}$ & $3.13 \pm 0.47^{\mathrm{de}}$ & $0.86 \pm 0.14^{\mathrm{bc}}$ & $78.04 \pm 3.50^{\mathrm{bc}}$ & $21.40 \pm 3.52^{\mathrm{ab}}$ \\
"Sair" & $3.26 \pm 0.31^{\mathrm{e}}$ & $2.51 \pm 0.30^{\mathrm{e}}$ & $0.73 \pm 0.12^{\mathrm{c}}$ & $77.00 \pm 3.50^{\mathrm{a}}$ & $22.41 \pm 3.63^{\mathrm{ab}}$ \\
\hline
\end{tabular}

for "Boufgous" $(9.45 \pm 0.22 \%)$ and "Bousthammi" $(10.34 \pm 0.37 \%)$ but slightly higher than "Majhoul" $(7.29 \pm 0.17 \%)$. Varieties studied here demonstrated higher amounts of date seeds, which represent important opportunities for valorization.

3.2. Proximate Composition, Energy Value, and Reducing Capacity. Proximate composition, associated EV, and RC for date fleshes and seeds are shown in Table 2. As can be seen, significant variations were found among the studied date varieties for almost all the evaluated parameters. For fruit flesh, CC exceeded $76 \%$ of the total composition, with the best record being presented by "Bouskri" (90.18\%). These results were consistent with published literature [15, 27]. CC found in flesh date fruit consist mainly of reducing sugars and dietary fibers are a minor fraction. Reducing sugars consist mainly of glucose and fructose (about 70-80\%), which contribute to the sweet taste and are easily absorbed into the human body to provide energy quickly $[28,29]$. Similarly, in date seeds, CC were reported to be the major constituents (over $83 \%$ of total composition). Their concentrations ranged from 83.39 ("Ismmarti") to $85.55 \%$ ("Amouch"). These outcomes were in full agreement with values found in literature with the predominance of dietary fibers $[12,29,30]$. This suggests the use of date seed powder to enrich processed foods in fibers. With respect to PC, seeds were rich in proteins compared to the flesh. For the studied varieties, PC ranged from $1.60 \pm 0.11 \%$ obtained in "Boufgous" to $3.53 \pm 0.20 \%$ obtained in "Jihel" for flesh part and from $3.20 \pm 0.21 \%$ in "Amouch" to $5.00 \pm 0.10 \%$ in "Ismmarti" for seeds part. Our findings were in line with other works carried out in Morocco and abroad involving several varieties [27, 31, 32]. Date fruits showed higher PC than other fruits such as apples $(0.3 \%)$, oranges $(0.7 \%)$, bananas $(1.0 \%)$, and grapes (1.0\%) [33]. These values were similar to those reported in date fleshes and seeds in some independent studies $[2,5,15]$. Date proteins vary widely depending not only on genotype but also on environments under which dates are grown and in developmental stage [34]. According to these authors, date pulp protein consists of water-soluble albumins with predominance of acidic amino acids, while sulfur containing amino acids are found in minor fractions. Likewise, important amounts of essential amino acids $[34,35]$ are found in date fruits.
OC (Table 2) was found to vary significantly among studied varieties $(p<0.05)$ and ranged from $6.30 \pm 0.01 \%$ ("Agondari") to $7.40 \pm 0.31 \%$ ("Sair") in the investigated date seeds. In contrast, lower OC values were found in date fleshes ranging from $0.32 \pm 0.03 \%$ ("Bouskri") to $1.09 \pm 0.09 \%$ ("Agondari”). Our results regarding OC were comparable to previously published values for date seeds and fleshes in Moroccan and foreign varieties [15, 30, 36]. However, Besbes et al. [12] found higher values of seed OC in two Tunisian cultivars, namely, "Deglet Nour" (10.19\%) and "Allig" (12.67\%). Such variations in seed and flesh oil content could be assigned to genotypic factors and environmental conditions along with the ripening stage at which date fruits are harvested $[6,34,35]$.

EVs associated with date fleshes and seeds (Table 2) showed trend of variations similar to those of CC, PC, and OC with significant variations among varieties. Date fleshes appeared to have lower energy values than seeds, which were linked to higher OC (known for its higher EV as compared to PC or CC). Moreover, "Agondari" was found to present the lowest record of EV for both date fleshes (338.30) and seeds (417.06 kcal/100 g), while "Bouskri" displayed the greatest values in fleshes (385.89) and seeds (429.51 kcal/100 g).

In literature, many studies were devoted to assessing $\mathrm{EV}$ in date fruits. Bouhlali et al. [15] found lower values of energy from date seeds belonging to three Moroccan varieties. Likewise, while investigating nutritional value in flesh fruits from 22 date varieties grown in Sultanate of Oman, AlHarrasi et al. [5] found energy values similar to ours. As discussed above, a set of factors (genotype, environment, and ripening stage) are behind the variations in PC, CC, and $\mathrm{OC}$ and, therefore, impact also on EVs, given the positive association between these compositional attributes on one hand and energy value on the other hand.

$\mathrm{MC}$ is one of the essential constituents of the fruit and it has a fundamental importance on its conservation [34]. The $\mathrm{MC}$ was found to vary significantly among the studied varieties and ranged from $5.31 \pm 0.42 \%$ ("Bouskri") to $17.31 \pm 3.20 \%$ ("Agondari") for date fleshes. For date seeds, "Bouskri" displayed the lowest value of MC $(1.42 \pm 0.03 \%)$, while the greatest one was found in "Boufgous" $(4.14 \pm 0.02 \%)$. Taouda et al. [4] reported higher values of $\mathrm{MC}$ in flesh fruits from three Moroccan date varieties: "Boufgous" (26.70\%), "Bouskri" (25.00\%), and "Jihel" (24.00\%). Also, Al-Harrasi et al. [5] found slightly higher MC levels in 22 date varieties from Oman. The 


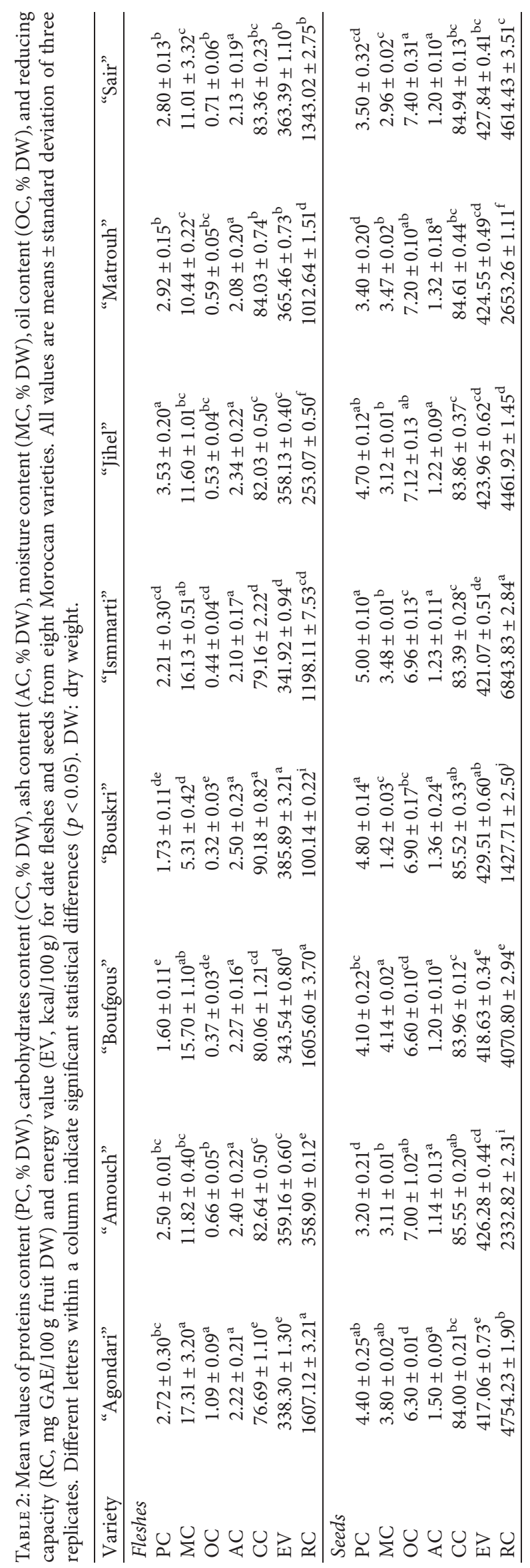


same picture was reflected for seeds, which presented slightly lower values of $\mathrm{MC}$ than those reported for some Moroccan [15] and Tunisian varieties [12]. However, our results for moisture levels in fleshes and seeds were consistent with those found in the work of Ahmed et al. [34]. Such differences in MC could be assigned to climatic conditions (water availability) under which date fruits are grown. It is also important to note that date fruits moisture was reported to decrease drastically during ripening to reach its small value at the Tamar stage [34]. Higher MC makes the dates susceptible to microbial colonization, including that of the fungal flora, so the low water content allows better conservation of the dates [4]. In this context, good hygienic practices should be undertaken to avoid microbial colonization.

AC was found to be higher in fleshes as compared to seeds. However, not much variation was outlined among varieties (Table 2). For date fleshes, AC ranged from $2.10 \pm 0.17$ ("Ismmarti") to $2.50 \pm 0.23 \%$ ("Bouskri"), while seed AC values varied from $1.14 \pm 0.13$ ("Amouch") to $1.50 \pm 0.09 \%$ ("Agondari"). These outcomes were close to those reported in literature for several Moroccan and foreign date varieties $[12,15,30]$. As discussed in the work of Ahmed et al. [34], AC decreased with ripening advancement, with Tamar stage being marked by the highest level of minerals, which seems to be linked to the decrease of fruit MC.

For RC (Table 2), date seeds displayed higher records of $\mathrm{RC}$ as compared to fleshes with a significant varietal effect $(p<0.05)$. In date seeds, the highest concentration of RC was found in "Ismmarti" (6843.83 \pm 2.84$)$, while the lowest one was recorded in "Bouskri" (1427.71 $\pm 2.50 \mathrm{mg} \mathrm{GAE} / 100 \mathrm{~g}$ of seeds dry weight). For fleshes, RC ranged from $100.14 \pm 0.22$ to $1605.60 \pm 3.70 \mathrm{mg}$ GAE/ $100 \mathrm{~g}$ date flesh dry weight. The two varieties "Agondari" and "Boufgous" had higher RC values (1607.12 \pm 3.21 and $1605.60 \pm 3.73 \mathrm{mg}$ GAE/100 g, respectively) and "Bouskri" presented the lowest concentration $(100.14 \pm 0.22 \mathrm{mg} \mathrm{GAE} / 100 \mathrm{~g})$. Our values for RC were in the range of published literature $(22.8-7486 \mathrm{mg}$ GAE/100 $\mathrm{g}$ fresh or dry weight) as reviewed by Sirisena et al. [29]. Likewise, similar results were reported in several varieties grown in Morocco and abroad [15, 37, 38]. In contrast, lower levels of polyphenols were reported by other authors $[39,40]$ who found a maximum of $6.73 \mathrm{mg}$ GAE/ $100 \mathrm{~g}$ for the pulp and $48.64 \mathrm{mg}$ GAE/100 $\mathrm{g}$ for date seeds, respectively. RC values reported in our work showed the richness of Moroccan date varieties as compared to other popular fruits such as pineapple (94 mg GAE/100 g FW), kiwi (88 mg GAE/100 g), red grape (80 mg GAE/100 g), red apple (74 mg GAE/100 g fresh weight), and green citrus (54 mg GAE/100 g FW) as outlined in the work of Fu et al. [41]. Such differences could be assigned to the difference among varieties, growing conditions, ripening, growing season, geographic origin, agronomic managements, and storage conditions, among others [37, 38, 42, 43]. The main phenolic compounds found in date fruits are gallic acid, catechin, ferulic acid, rutin, syringic, and p-coumaric acid $[6,37,38]$, which make date fruits excellent antioxidants, as recently reviewed by Maqsood et al. [43]. Many other studies confirm that phenolic compounds have a protective effect on human health $[44,45]$. Epidemiological studies show a correlation between the consumption of polyphenols (flavonoids) and the reduced incidence of chronic diseases such as cardiovascular disease, diabetes, and cancer [46, 47].

3.3. Mineral Composition. The benefits of minerals to human health are well proved and documented. Minerals are involved in many functions in the human body, including bone and teeth health, nervous system, blood regulation, red blood cell production, and other functions [48]. Many previous studies have been carried out to investigate minerals in date fruits and have proved that dates are great sources of minerals. The obtained results of AC and minerals in this study are summarized in Table 2 and Table 3, respectively. AC of the flesh part was almost the same for all varieties and ranged between $2.08 \pm 0.20$ and $2.50 \pm 0.23 \%$. These results were similar to those reported by El-Sohaimy and Hafez [49]. The seed part showed lower concentrations than the flesh and ranged between $1.14 \pm 0.13$ and $1.50 \pm 0.09 \%$.

Nine minerals have been analyzed $(\mathrm{K}, \mathrm{Ca}, \mathrm{Mg}, \mathrm{B}, \mathrm{Fe}, \mathrm{Cu}$, $\mathrm{Zn}, \mathrm{Mn}$, and $\mathrm{Na}$ ) in fleshes and seeds. As expected, potassium was the highest element, followed by magnesium and calcium, in all the studied varieties for both fruit parts (flesh and seed), with significant varietal differences for almost all minerals. Similar trends were noticed by other authors for date flesh $[15,50,51]$. With respect to date fleshes, values of $K$ (4095.1 $\pm 372.0-12047.1 \pm 1096.0), \quad$ Ca $\quad(278.9 \pm 25.0-1244.0$ $\pm 113.0)$, and $\mathrm{Mg}(297.1 \pm 27.0-1155.7 \pm 105.0 \mathrm{mg} / \mathrm{kg})$ were in agreement with those found by Ali-Mohamed and Khamis [52]. Corresponding values, in date seeds, of $\mathrm{K}$ (3956.6 $\pm 360.0-6127.6 \pm 557.0)$, Ca $(312.5 \pm 28.0-800.3 \pm 72.0)$, and $\mathrm{Mg}(583.8 \pm 53.0-1001.3 \pm 91.0 \mathrm{mg} / \mathrm{kg})$ were consistent with those found by Habib and Ibrahim [30]. Similar results for minerals were recently reported by Bijami et al. [53] for date seeds from "Mozafati" cultivar grown in Iran. According to these authors, seed mineral levels decrease during developmental stages to reach the lowest values at Tamar stage. The concentration obtained for each element varied significantly among varieties; this could be explained by the difference in needs and absorption of minerals for each variety. The highest concentrations of potassium, calcium, and magnesium were found in "Bouskri," "Boufgous," and "Amouch," respectively. Among the trace metals, iron was the highest element in the flesh $(8.8 \pm 0.8$ to $24.4 \pm 2.2 \mathrm{mg} / \mathrm{kg})$ and seed $(8.0 \pm 0.7$ to $79.5 \pm 7.2 \mathrm{mg} / \mathrm{kg}$ ) with large variations among varieties. Our results regarding the major elements $(\mathrm{K}, \mathrm{Ca}$, and $\mathrm{Mg}$ ) were greater than those found by $\mathrm{Al}$ Juhaimi et al. [54] in different date fruits obtained in Saudi Arabia. However, the concentration found for trace elements was close to those reported in the same study for the flesh part. It is also useful to point out that the seeds contained fewer minerals than fleshes but their content of essential elements allows them to be better valued in other industries and be much more profitable in use as an animal feed.

3.4. Fatty Acid Composition. To evaluate the added value of the composition of the date seed oils, we have focused on analyzing the fatty acid profile. This family of compounds is 


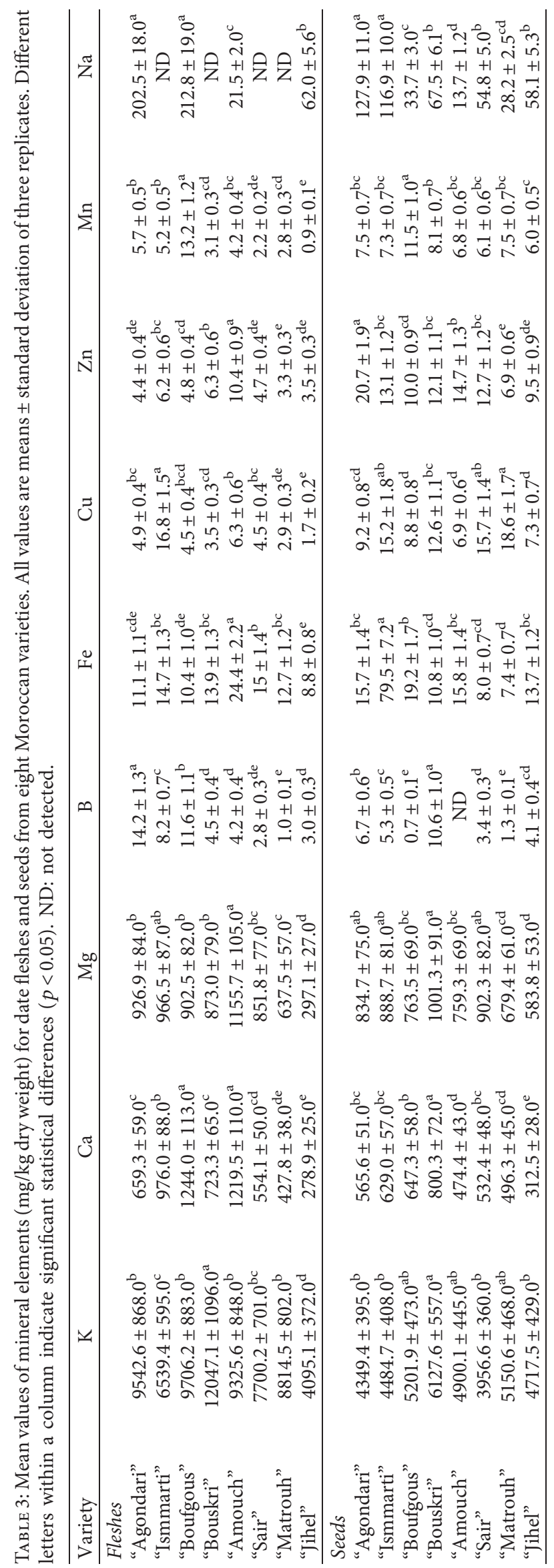


TABLE 4: Mean values of fatty acids (in \%) of date seed oils from eight date palm Moroccan varieties. All values are mean \pm standard deviation of three replicates. Different letters within a column indicate significant statistical differences $(p<0.05)$. SFA: saturated fatty acids, MUFA: monounsaturated fatty acids, and PUFA: polyunsaturated fatty acids.

\begin{tabular}{|c|c|c|c|c|c|c|c|c|c|}
\hline & "Agondari" & "Bouskri" & "Ismmarti" & "Jihel" & "Matrouh" & "Sair" & "Amouch" & "Boufgous" & Average \\
\hline C12:0 & $18.6 \pm 0.1^{\mathrm{ab}}$ & $19.4 \pm 3.8^{\mathrm{ab}}$ & $16.5 \pm 0.5^{\mathrm{b}}$ & $16.7 \pm 0.1^{\mathrm{ab}}$ & $19.5 \pm 1.1^{\mathrm{ab}}$ & $20.6 \pm 0.7^{\mathrm{a}}$ & $16.2 \pm 0.2^{\mathrm{b}}$ & $16.7 \pm 0.5^{\mathrm{ab}}$ & $18.0 \pm 1.7$ \\
\hline $\mathrm{C} 14: 0$ & $11.3 \pm 0.1^{\mathrm{a}}$ & $10.4 \pm 0.9^{\mathrm{ab}}$ & $10.3 \pm 0.2^{\mathrm{ab}}$ & $10.0 \pm 0.1^{b c}$ & $11.3 \pm 0.5^{\mathrm{a}}$ & $11.1 \pm 0.5^{\mathrm{ab}}$ & $9.6 \pm 0.1^{\mathrm{c}}$ & $10.2 \pm 0.2^{\mathrm{ab}}$ & $10.5 \pm 0.6$ \\
\hline $\mathrm{C} 16: 0$ & $10.2 \pm 0.1^{b}$ & $10.8 \pm 0.1^{\mathrm{a}}$ & $11.1 \pm 0.0^{\mathrm{a}}$ & $11.0 \pm 0.0^{\mathrm{a}}$ & $10.0 \pm 0.2^{\mathrm{b}}$ & $10.1 \pm 0.2^{\mathrm{b}}$ & $11.0 \pm 0.1^{\mathrm{a}}$ & $10.9 \pm 0.2^{\mathrm{a}}$ & $10.6 \pm 0.4$ \\
\hline $\mathrm{C} 16: 1$ & $0.1 \pm 0.0^{\mathrm{a}}$ & $0.0 \pm 0.0^{c}$ & $0.1 \pm 0.0^{\mathrm{a}}$ & $0.1 \pm 0.0^{\mathrm{a}}$ & $0.1 \pm 0.0^{\mathrm{a}}$ & $0.1 \pm 0.0^{\mathrm{a}}$ & $0.1 \pm 0.0^{\mathrm{a}}$ & $0.1 \pm 0.0^{\mathrm{b}}$ & $0.1 \pm 0.0$ \\
\hline $\mathrm{C} 17: 0$ & $0.1 \pm 0.0^{\mathrm{a}}$ & $0.0 \pm 0.0^{c}$ & $0.0 \pm 0.0^{c}$ & $0.0 \pm 0.0^{c}$ & $0.0 \pm 0.0^{c}$ & $0.0 \pm 0.0^{c}$ & $0.0 \pm 0.0^{\mathrm{b}}$ & $0.0 \pm 0.0^{b}$ & $0.1 \pm 0.0$ \\
\hline $\mathrm{C} 18: 0$ & $3.1 \pm 0.0^{\mathrm{d}}$ & $4.0 \pm 0.4^{\mathrm{ab}}$ & $3.3 \pm 0.0^{\mathrm{cd}}$ & $4.2 \pm 0.0^{\mathrm{a}}$ & $3.4 \pm 0.1^{\mathrm{cd}}$ & $3.6 \pm 0.1^{b c}$ & $3.4 \pm 0.0^{\mathrm{cd}}$ & $3.7 \pm 0.1^{b c}$ & $3.6 \pm 0.4$ \\
\hline $\mathrm{C} 18: 1$ & $46.6 \pm 0.2^{\mathrm{ab}}$ & $46.5 \pm 3.3^{\mathrm{ab}}$ & $48.2 \pm 0.4^{\mathrm{ab}}$ & $50.1 \pm 0.1^{\mathrm{a}}$ & $45.9 \pm 1.2^{\mathrm{bc}}$ & $44.0 \pm 1.0^{\mathrm{c}}$ & $49.9 \pm 0.2^{\mathrm{a}}$ & $48.7 \pm 0.9^{\mathrm{ab}}$ & $47.5 \pm 2.1$ \\
\hline $\mathrm{C} 18: 2$ & $9.3 \pm 0.0^{\mathrm{a}}$ & $8.0 \pm 0.7^{\mathrm{C}}$ & $9.7 \pm 0.1^{\mathrm{a}}$ & $7.0 \pm 0.0^{\mathrm{d}}$ & $9.0 \pm 0.3^{\mathrm{ab}}$ & $9.7 \pm 0.2^{\mathrm{a}}$ & $9.0 \pm 0.0^{\mathrm{ab}}$ & $8.7 \pm 0.1^{b c}$ & $8.8 \pm 1.0$ \\
\hline $\mathrm{C} 18: 3$ & $0.1 \pm 0.0^{\mathrm{a}}$ & $0.1 \pm 0.0^{\mathrm{a}}$ & $0.1 \pm 0.0^{\mathrm{a}}$ & $0.1 \pm 0.0^{\mathrm{a}}$ & $0.1 \pm 0.0^{\mathrm{a}}$ & $0.1 \pm 0.0^{\mathrm{a}}$ & $0.1 \pm 0.0^{\mathrm{a}}$ & $0.1 \pm 0.0^{\mathrm{a}}$ & $0.1 \pm 0.0$ \\
\hline $\mathrm{C} 20: 0$ & $0.3 \pm 0.0^{\mathrm{b}}$ & $0.5 \pm 0.1^{\mathrm{a}}$ & $0.4 \pm 0.0^{\mathrm{ab}}$ & $0.5 \pm 0.0^{\mathrm{a}}$ & $0.4 \pm 0.0^{\mathrm{ab}}$ & $0.4 \pm 0.0^{\mathrm{ab}}$ & $0.4 \pm 0.0^{\mathrm{ab}}$ & $0.5 \pm 0.0^{\mathrm{a}}$ & $0.4 \pm 0.1$ \\
\hline $\mathrm{C} 20: 1$ & $0.3 \pm 0.0^{\mathrm{b}}$ & $0.3 \pm 0.1^{\mathrm{b}}$ & $0.3 \pm 0.0^{\mathrm{b}}$ & $0.3 \pm 0.0^{\mathrm{b}}$ & $0.3 \pm 0.0^{\mathrm{b}}$ & $0.3 \pm 0.0^{\mathrm{b}}$ & $0.3 \pm 0.0^{\mathrm{b}}$ & $0.4 \pm 0.0^{\mathrm{a}}$ & $0.3 \pm 0.0$ \\
\hline$\Sigma$ SFA & 43.6 & 45.1 & 41.6 & 42.4 & 44.6 & 45.8 & 40.6 & 42.0 & 43.2 \\
\hline$\Sigma$ MUFA & 47.0 & 46.8 & 48.6 & 50.5 & 46.3 & 44.4 & 50.3 & 49.2 & 47.9 \\
\hline$\sum$ PUFA & 9.4 & 8.1 & 9.8 & 7.1 & 9.1 & 9.8 & 9.1 & 8.8 & 8.9 \\
\hline Total & 100.0 & 100.0 & 100.0 & 100.0 & 100.0 & 100.0 & 100.0 & 100.0 & 100.0 \\
\hline
\end{tabular}

an essential indicator of its nutritional value and suitability for the cosmetics, mostly unsaturated fatty acids [55]. Additionally, fatty acids are important components of the saponifiable fraction in vegetable oils. Table 4 shows the fatty acid profile of the eight date seed oils. Our results showed that the date seed oil contained three types of fatty acids with important variations among varieties. Indeed, the monounsaturated fatty acids were the most abundant, accounting for $47.9 \pm 2.1 \%$ followed by saturated fatty acids $(43.2 \pm 7.1 \%)$, and closely followed by polyunsaturated fatty acids $(8.9 \pm 1.1 \%)$.

The main saturated fatty acids of the date seeds oils in ascending order were stearic acid (3.6 $\pm 0.4 \%)$, myristic acid $(10.5 \pm 0.6 \%)$, palmitic acid (and $10.6 \pm 0.4 \%)$, and lauric acid $(18.0 \pm 1.7 \%)$. The date seed oils also contain important amounts of unsaturated normal chain fatty acids, especially oleic acid $(47.5 \pm 2.1 \%)$ and linoleic acid $(8.8 \pm 1.0 \%)$. In our results, all the oils showed that oleic acid was the dominant fatty acid. So, this date seed oil belongs to the oleic acid group. Nevertheless, linolenic acid is a minority and its concentration was about $0.1 \pm 0.0 \%$. These results were consistent with published literature $[1,12,15]$. Thanks to this low level of unsaturation, date seed oils may have an interesting potential for different uses as discussed in the work of Besbes et al. [12].

The minimum content of linolenic acid can be used to detect adulteration of some vegetable oils with other oils rich in linoleic acid such as nut, soybean, and rapeseed oils. For the other fatty acids, apart from C18:0, which displayed an average value of $3.6 \pm 0.4 \%$, the remaining fatty acids (C16: 1, C17:0, and C18:3) were found to have lower records, since their concentrations were below $0.1 \%$. Our findings regarding fatty acids were consistent with previously published literature $[1,12,30,34]$. These authors highlighted the predominance of oleic and linoleic acids with significant varietal effects, while ripening stage along with pedoclimatic conditions accounts for significant variations and therefore should be taken into account when processing date seed.
3.5. Principal Component Analysis. PCA was proven to be an efficient discriminative approach [56-58] used as a multivariate statistical method to discriminate among date palm varieties on one hand and between fruit fleshes and seeds on the other hand based on the studied fruit physical and chemical traits steps (dependent variables). The two first principal components (PCs) were retained because they allowed explaining over $70 \%$ of the total data variability. Points plotted on the surface determined by axes 1 and 2 (Figure 1(a)) are related to varieties plotted against physical fruit traits, which seem to be separated along with the first component (PC1). Toward the positive direction of $\mathrm{PC} 1$, the varieties including "Ismmarti," "Boufgous," "Amouch," and "Jihel" interacted with higher scores of SW, FW, fW, and fP, while the remaining four varieties were associated with the best scores of SP. Similarly, points plotted on the plan determined by axes 1 and 2 were linked to date palm varieties as independent variables, which were plotted against proximate composition, EV, RC, and mineral elements as dependent variables (Figure 1(b)). It seems that the three varieties ("Jihel," "Matrouh," and "Sair") were associated, on the positive side of the second component (PC2), to higher records of PC. On the opposite side, "Ismmarti," "Agondari," and "Boufgous" interacted with greater values of RC and mineral elements. Moreover, both "Bouskri" and "Amouch" were not clearly separated via the second component.

Figure 1(c) presents the distribution of fruit parts (independent variables) versus proximate composition, $\mathrm{EV}, \mathrm{RC}$, and mineral elements as dependent variables on the surface determined by PC1 and PC2. From these outcomes, fruit parts (fleshes and seeds) were distributed according to PC1. On the positive side of this component, seeds were associated with the greatest P, OC, CC, EV, RC, and various minerals ( $\mathrm{Fe}, \mathrm{Cu}, \mathrm{Mn}$, and $\mathrm{Zn}$ ). At the same time, fleshes were characterized by the highest values of ash, moisture content, and different mineral elements ( $B$, $\mathrm{Ca}, \mathrm{K}, \mathrm{Mg}$, and $\mathrm{Na}$ ). Finally, Figure 1(d) summarizes 


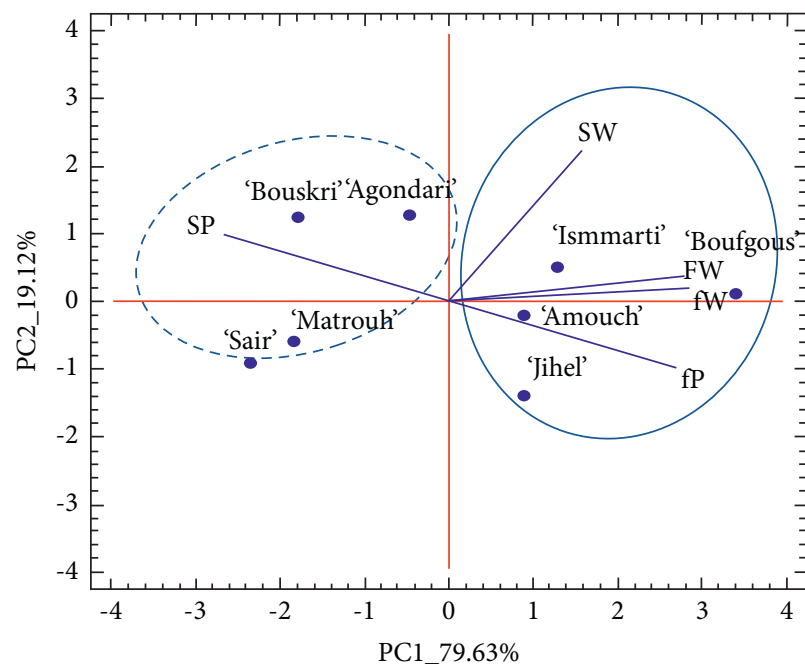

(a)

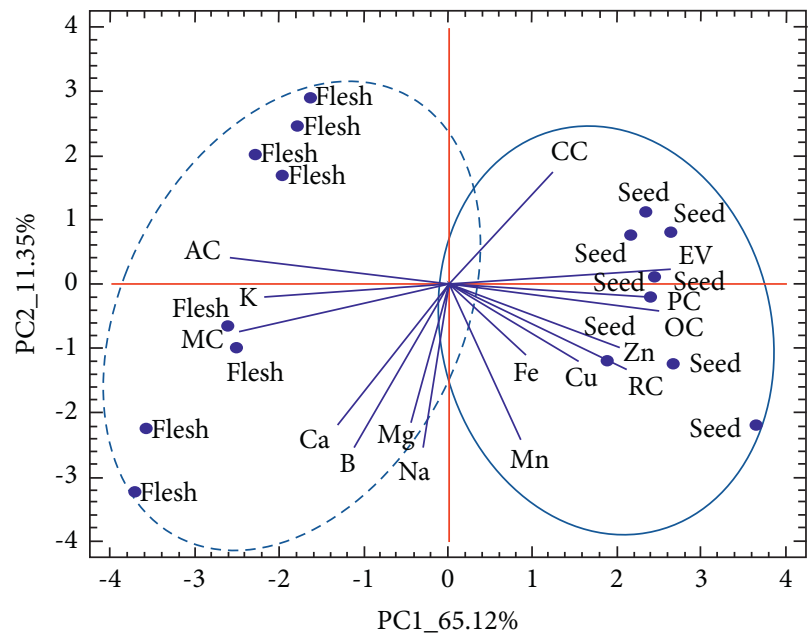

(c)

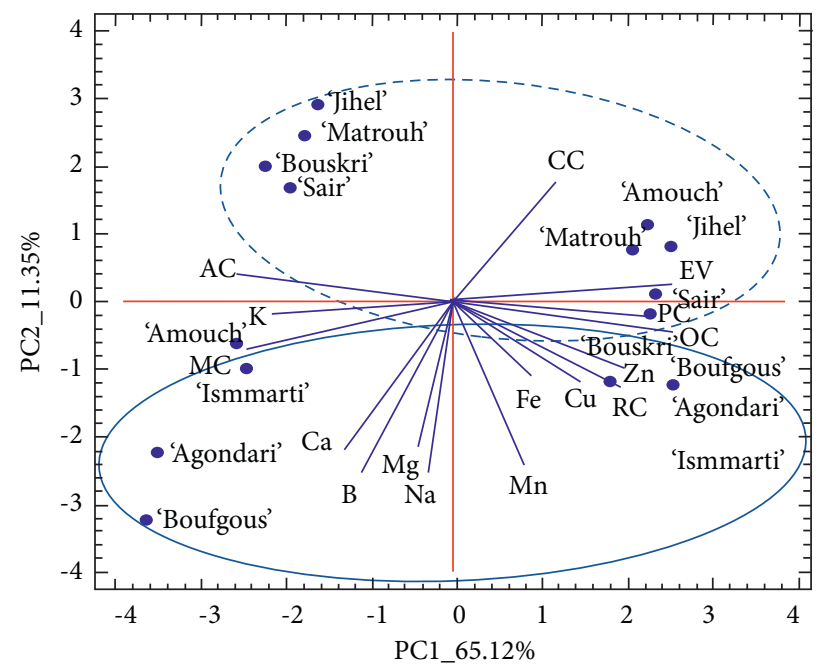

(b)

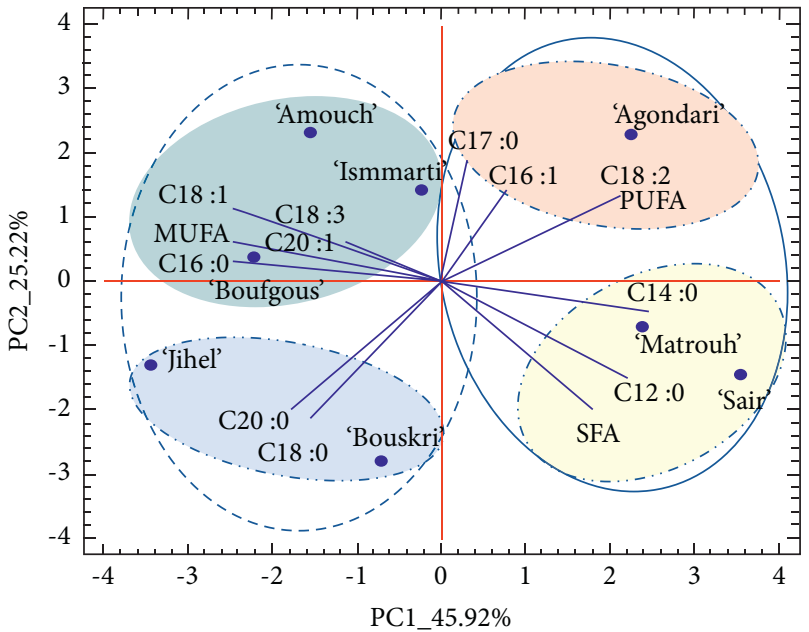

(d)

Figure 1: Principal component analysis (PCA) projections on PC1 and PC2. Eigenvalues are symbolized as blue segments representing parameters that most affect each principal component. Plotted points are mean values of each studied parameter of various date palm varieties. FW: fruit weight, fW: flesh weight, SW: seed weight, fP: flesh percentage, SP: seed percentage, AC: Ash content, CC: carbohydrates content, PC: protein content, EV: energy value, OC: oil content, MC: moisture content, RC: reducing capacity. C12:0: lauric acid, C14:0: myristic acid, C16: 0: palmitic acid, C16:1: palmitoleic acid, C17:0: margaric acid, C18:0: stearic acid, C18:1: oleic acid, C18:2: linoleic acid, C18: 3: linolenic acid, C20:0: arachidic acid, C20:1: gadoleic acid, SFA: saturated fatty acids, MUFA: monounsaturated fatty acids, and PUFA: polyunsaturated fatty acids.

interactions between date palm varieties as independent variables on one hand and fatty acids content as dependent variables on the other hand. Varieties seemed to be plotted following the first component PC1. Both "Matrouh" and "Sair" were linked to higher levels of C12: $0, \mathrm{C} 14: 0$, and SFA on the positive side of PC1, while "Agondari" was associated with the best records of C18:2 and PUFA. On the contrary, both "Jihel" and "Bouskri" were distributed toward the negative direction of PC1 with higher values of $\mathrm{C} 18: 0$ and C20:0. In comparison "Amouch," "Ismmarti," and "Boufgous" were marked by higher values of C16:0, C18:1, C20:1, and MUFA. In the literature, PCA is widely used, as a discriminative tool, among varieties and environments based on fruit traits
[18]. Al-Harrasi et al. [5] successfully separated 22 date palm dates grown in Oman based on nutritional and chemical profiling combined with PCA. Similar results were highlighted in the work of Abdul-Hamid et al. [27] for five varieties from Saudi Arabia, Tunisia, and Iran.

\section{Conclusions}

Flesh date fruit is of major interest from a nutritional perspective as a source of several nutritional elements. Date seed, usually used as an ingredient in human health and cosmetic as well as pharmaceutical field especially, is less valued. The nutritional and chemical analysis of date fruit varieties demonstrated higher PC, OC, CC, EV, and 
RC in both fruit parts (flesh and seed) with important varietal differences. "Boufgous" presented the greatest values of FW, fW, and fP, while "Agondari" and "Bouskri" presented the best records of SW and SP, respectively. Likewise, the greatest values of nutritional traits were displayed by "Agondari" (MC, OC, RC, and B), "Amouch" $(\mathrm{Mg}, \mathrm{Fe}$, and $\mathrm{Zn})$, "Boufgous" ( $\mathrm{Ca}, \mathrm{Mn}$, and $\mathrm{Na}$ ), "Bouskri" (AC, CC, EV, and $\mathrm{K})$, "Ismmarti" (Cu), and "Jihel" (PC) for fruit fleshes. Regarding date seeds, the highest records were presented by "Agondari" ( $\mathrm{AC}, \mathrm{Zn}$, and $\mathrm{Na}$ ), "Amouch" (CC), "Boufgous" (MC and Mn), "Bouskri" (K, $\mathrm{Ca}, \mathrm{Mg}$, and $\mathrm{B}$ ) "Ismmarti" (PC, RC, $\mathrm{Fe}$, and PUFA), "Jihel" (MUFA), "Matrouh" ( $\mathrm{Cu}$ ), and "Sair" (OC, SFA, and PUFA). The main mineral elements present in date fruit varieties are calcium, magnesium, and potassium, with considerable variability. Potassium is the highest element in the seed and the flesh in all varieties. Date seed oil includes three types of fatty acids. Monounsaturated fatty acids are the largest class of fatty acids followed by saturated fatty acids and closely succeeded by polyunsaturated fatty acids. Our results indicate that oleic acid is the major unsaturated fatty acid in all varieties. This last fatty acid is an important element of the diet; it is highly appreciated because of its high health benefits. Given their nutritional richness, seeds could offer important opportunities for valorization, such as a food additive.

\section{Data Availability}

The data used to support the findings of this work are available, upon request, from the corresponding author.

\section{Conflicts of Interest}

There are no conflicts of interest to declare.

\section{Authors' Contributions}

Mohamed Ibourki provided the resources and reviewed and edited the article; Fadma Azouguigh conceptualized the study, developed the methodology, performed formal analysis, performed investigation, provided the resources, and wrote the original draft; Si Mohamed Jadouali provided the resources, reviewed and edited the article; El Hassan Sakar acquired the data and reviewed and edited the article; Laila Bijla acquired the data, reviewed and edited the article; Khalid Majourhat acquired the data, performed interpretation, reviewed and edited the article; Said Gharby supervised the study, provided the resources and software, reviewed and edited the article; and Abdelatif Laknifli acquired the data, performed interpretation, and reviewed and edited the article.

\section{Acknowledgments}

The authors would like to thank Association Ibn Al Baytar, HSB, cooperative AZMIR (Tata), and dates agriculture cooperatives (Er-Rachidia) for their support and kind assistance in this work.

\section{References}

[1] H. M. Habib, H. Kamal, W. H. Ibrahim, and A. S. A. Dhaheri, "Carotenoids, fat soluble vitamins and fatty acid profiles of 18 varieties of date seed oil," Industrial Crops and Products, vol. 42, pp. 567-572, 2013.

[2] A. M. E. Sulieman, I. A. A. Elhafise, and A. M. Abdelrahim, "Comparative study on five Sudanese date (Phoenix dactylifera L.) fruit cultivars," Food Sciences and Nutrition, vol. 03, no. 9, pp. 1245-1251, 2012.

[3] H. Sedra, Date Palm Farmer Guide: Implementation and Management of Date Palm Orchards, INRA, Rabat, Morocco, 2012.

[4] H. Taouda, M. M. Alaoui, F. Errachidi, R. Chabir, and L. Aarab, "Comparative study of the morpho-metric and Biochemical dates caractere solding in the regional market of FEZ/Morocco," International Journal of Innovation and Applied Studies, vol. 8, no. 1, pp. 1-10, 2014.

[5] A. Al-Harrasi, N. U. Rehman, J. Hussain et al., "Nutritional assessment and antioxidant analysis of 22 date palm (Phoenix dactylifera) varieties growing in Sultanate of Oman," Asian Pacific Journal of Tropical Medicine, vol. 7, no. 1, pp. S591S598, 2014.

[6] F. Benmeziane-Derradji, "Nutritional value, phytochemical composition, and biological activities of Middle Eastern and North African date fruit: an overview," Euro-Mediterranean Journal for Environmental Integration, vol. 4, no. 1, p. 39, 2019.

[7] M. Salman Haider, I. A. Khan, and S. A. Naqvi, "Fruit developmental stages effects on biochemical attributes in date palm," Pakistan Journal of Agricultural Sciences, vol. 50, no. 4, pp. 577-583, 2013.

[8] M. Siddiq and I. Greiby, "Overview of date fruit production, postharvest handling, processing and nutrition," in Dates: Postharvest Science, Processing Technology And Health Benefits, M. Siddiq, S. M. Aleid, and A. A. Kader, Eds., John Wiley \& Sons Ltd, Chichester, UK, 2013.

[9] I. Diboun, S. Mathew, M. Al-Rayyashi et al., "Metabolomics of dates (Phoenix dactylifera) reveals a highly dynamic ripening process accounting for major variation in fruit composition," BMC Plant Biology, vol. 15, p. 291, 2015.

[10] A. G. Tafti, N. Solaimani Dahdivan, and S. A. Yasini Ardakani, "Physicochemical properties and applications of date seed and its oil," International Food Research Journal, vol. 24, pp. 1399-1406, 2017.

[11] M. S. Baliga, B. R. V. Baliga, S. M. Kandathil, H. P. Bhat, and P. K. Vayalil, "A review of the chemistry and pharmacology of the date fruits (Phoenix dactylifera L.)," Food Research International, vol. 44, no. 7, pp. 1812-1822, 2011.

[12] S. Besbes, C. Blecker, C. Deroanne, N.-E. Drira, and H. Attia, "Date seeds: chemical composition and characteristic profiles of the lipid fraction," Food Chemistry, vol. 84, no. 4, pp. 577-584, 2004.

[13] M. A. Al-Farsi and C. Y. Lee, "Usage of date (Phoenix dactylifera L.) seeds in human health and animal feed," in Nuts And Seeds in Health and Disease Prevention, V. R. Preedy, R. R. Watson, and V. B. Patel, Eds., Academic Press, London, UK, pp. 447-452, 2011.

[14] Food and Agriculture Organization Corporate Statistical Database, FAO Statistical Yearbook, Rome, Italy, 2020.

[15] E. D. T. Bouhlali, C. Alem, J. Ennassir, M. Benlyas, A. N. Mbark, and Y. F. Zegzouti, "Phytochemical compositions and antioxidant capacity of three date (Phoenix dactylifera L.) seeds varieties grown in the South East Morocco," 
Journal of the Saudi Society of Agricultural Sciences, vol. 16, no. 4, pp. 350-357, 2017.

[16] M. Kirthy Reddy, H. Durga Rani, C. Naga Deepika, S. Samrawat, V. Akshara, and K. Rajesh, "Study on physicochemical properties of oil and powder of date palm seeds (Phoenix dactylifera)," International Journal of Current Microbiology and Applied Sciences, vol. 6, no. 12, pp. 486-492, 2017.

[17] E. H. Sakar, M. El Yamani, A. Boussakouran, and Y. Rharrabti, "Codification and description of almond (Prunus dulcis) vegetative and reproductive phenology according to the extended $\mathrm{BBCH}$ scale," Scientia Horticulturae, vol. 247, pp. 224-234, 2019.

[18] E. H. Sakar, M. El Yamani, and Y. Rharrabti, "Fruit gravimetrical traits in almond [Prunus dulcis (mill.) D.A. Webb]: combined effects of genetic control and environmental drivers," Erwerbs-obstbau, vol. 62, no. 1, pp. 37-46, 2020.

[19] S. Gharby, H. Harhar, Z. Bouzoubaa, A. Asdadi, A. El Yadini, and Z. Charrouf, "Chemical characterization and oxidative stability of seeds and oil of sesame grown in Morocco," Journal of the Saudi Society of Agricultural Sciences, vol. 16, no. 2, pp. 105-111, 2017.

[20] AOAC, Official Methods of Analysis, Association of Official Analytical Chemists, Gaithersburg, MD, USA, 18th edition, 2005.

[21] E. V. Crisan and A. Sands, "Nutrition value," in Biology And Cultivation Of Edibles Mushrooms, S. T. Chang and W. A. Hayes, Eds., Academic Press, New York, NY, USA, 1978.

[22] F. A. E. Mohammed, R. Bchitou, A. Bouhaouss et al., "Can the dietary element content of virgin argan oils really be used for adulteration detection?" Food Chemistry, vol. 136, no. 1, pp. 105-108, 2013.

[23] I. Nounah, A. Hajib, and H. Harhar, "Chemical composition and antioxidant activity of lawsonia inermis seed extracts from Morocco," Natural Product Communications, vol. 12, no. 4, pp. 487-488, 2017.

[24] A. Telli, N. Mahboub, S. Boudjeneh, O. Siboukeur, and F. Moulti-Mati, "Optimisation des conditions d'extraction des polyphénols de dattes lyophilisées (Phoenix dactylifera L.) variété Ghars," Annales des Sciences et Technologie, vol. 2, no. 2, pp. 107-114, 2010.

[25] H. Harrak, M. Boujnah, and A. Hamouda, "Caractérisations physique et morphologique des principales variétés de dattes marocaines," Al Awamia, vol. 107, pp. 59-76, 2003.

[26] S. Acourene, K. Djafri, and A. Benchabane, "Dates quality assessment of the main date palm cultivars grown in Algeria," Annual Research \& Review in Biology, vol. 4, no. 3, pp. 487-499, 2014.

[27] N. A. Abdul-Hami, M. Maulidiani, and A. Mediani, "Physicochemical characteristics, nutritional composition, and phytochemical profiles of nine Algerian date palm fruit (Phoenix dactylifera L.) varieties," Journal of Food Biochemistry, vol. 42, no. 6, Article ID e12663, 2018.

[28] S. Ghnimi, M. Al-Shibli, H. R. Al-Yammahi et al., "Reducing sugars, organic acids, size, color, and texture of 21 Emirati date fruit varieties (Phoenix dactylifera , L.)," NFS Journal, vol. 12, pp. 1-10, 2018.

[29] S. Sirisena, K. Ng, and S. Ajlouni, "The emerging Australian date palm industry: date fruit nutritional and bioactive compounds and valuable processing by-products," Comprehensive Reviews in Food Science and Food Safety, vol. 14, no. 6, pp. 813-823, 2015.
[30] H. M. Habib and W. H. Ibrahim, "Nutritional quality evaluation of eighteen date pit varieties," International Journal of Food Sciences \& Nutrition, vol. 60, pp. 99-111, 2009.

[31] E. d. T. Bouhlali, M. Ramchoun, C. Alem, K. Ghafoor, J. Ennassir, and Y. F. Zegzouti, "Functional composition and antioxidant activities of eight Moroccan date fruit varieties (Phoenix dactylifera L.)," Journal of the Saudi Society of Agricultural Sciences, vol. 16, no. 3, pp. 257-264, 2017.

[32] M. K. Mahawar, K. Jalgaonkar, M. Kumar, V. S. Meena, and B. Bhushan, "Determination of some physical properties of date palm fruits (cv. Khadrawy and medjool)," Acta Agrophysica, vol. 24, no. 2, pp. 217-223, 2017.

[33] S. S. Al-Showiman, Al Tamr, Ghetha Wa Saha (Date, Food and Health), Dar Al-Khareji Press, Sharjah, UAE, 1998.

[34] J. Ahmed, F. M. Al-Jasass, and M. Siddiq, Date Fruit Composition and Nutrition. Dates: Postharvest Science, Processing Technology and Health Benefits, Wiley Blackwell, Chichester, UK, 2014.

[35] M. Chandrasekaran and A. H. Bahkali, "Valorization of date palm (Phoenix dactylifera) fruit processing by-products and wastes using bioprocess technology - Review," Saudi Journal of Biological Sciences, vol. 20, no. 2, pp. 105-120, 2013.

[36] A. A. M. Jaih, R. A. Rahman, A. F. A. Razis, A. A. Ariffin, A. Al-Awaadh, and N. Suleiman, "Fatty acid, triacylglycerol composition and antioxidant properties of date seed oil," International Food Research Journal, vol. 26, no. 2, pp. 517527, 2019.

[37] F. Al Juhaimi, M. M. Özcan, O. Q. Adiamo, O. N. Alsawmahi, K. Ghafoor, and E. E. Babiker, "Effect of date varieties on physico-chemical properties, fatty acid composition, tocopherol contents, and phenolic compounds of some date seed and oils," Journal of Food Processing and Preservation, vol. 42, no. 4, Article ID e13584, 2018.

[38] A. Alahyane, H. Harrak, J. Ayour, I. Elateri, A. Ait-Oubahou, and M. Benichou, "Bioactive compounds and antioxidant activity of seventeen Moroccan date varieties and clones (Phoenix dactylifera L.)," South African Journal of Botany, vol. 121, pp. 402-409, 2019.

[39] M. J. Abdul-Afiq, R. Abdul-Rahman, Y. B. Che Man, H. A. AlKahtani, and T. S. T. Mansor, "Date seed and date seed oil," International Food Research Journal, vol. 20, no. 5, pp. 2035-2043, 2013.

[40] A. Mansouri, G. Embarek, E. Kokkalou, and P. Kefalas, "Phenolic profile and antioxidant activity of the Algerian ripe date palm fruit (Phoenix dactylifera)," Food Chemistry, vol. 89, no. 3, pp. 411-420, 2005.

[41] L. Fu, B.-T. Xu, X.-R. Xu et al., "Antioxidant capacities and total phenolic contents of 62 fruits," Food Chemistry, vol. 129, no. 2, pp. 345-350, 2011.

[42] M. Al-Farsi, C. Alasalvar, M. Al-Abid, K. Al-Shoaily, M. AlAmry, and F. Al-Rawahy, "Compositional and functional characteristics of dates, syrups, and their by-products," Food Chemistry, vol. 104, no. 3, pp. 943-947, 2007.

[43] S. Maqsood, O. Adiamo, M. Ahmad, and P. Mudgil, "Bioactive compounds from date fruit and seed as potential nutraceutical and functional food ingredients," Food Chemistry, vol. 308, p. 125522, 2020.

[44] K. B. Pandey and S. I. Rizvi, "Plant polyphenols as dietary antioxidants in human health and disease," Oxidative Medicine and Cellular Longevity, vol. 2, no. 5, pp. 270-278, 2009.

[45] D. Vauzour, A. Rodriguez-Mateos, G. Corona, M. J. OrunaConcha, and J. P. E. Spencer, "Polyphenols and human health: prevention of disease and mechanisms of action," Nutrients, vol. 2, no. 11, pp. 1106-1131, 2010. 
[46] V. Habauzit and C. Morand, "Evidence for a protective effect of polyphenols-containing foods on cardiovascular health: an update for clinicians," Therapeutic Advances in Chronic Disease, vol. 3, no. 2, pp. 87-106, 2012.

[47] G. P. P. Lima, F. Vianello, C. R. Corrêa, R. A. d. S. Campos, and M. G. Borguini, "Polyphenols in fruits and vegetables and its effect on human health," Food and Nutrition Sciences, vol. 05, no. 11, pp. 1065-1082, 2014.

[48] I. Marmouzi, K. Ali, H. Harhar et al., "Functional composition, antibacterial and antioxidative properties of oil and phenolics from Moroccan Pennisetum glaucum seeds," Journal of the Saudi Society of Agricultural Sciences, vol. 17, no. 3, pp. 229-234, 2018.

[49] S. A. El-Sohaimy and E. E. Hafez, "Biochemical and nutritional characterizations of date palm fruits (Phoenix dactylifera L.)," Journal of Applied Sciences Research, vol. 6, no. 6, pp. 1060-1067, 2010.

[50] W. Al-Shahib and R. J. Marshall, "The fruit of the date palm: its possible use as the best food for the future?" International Journal of Food Sciences \& Nutrition, vol. 54, no. 4, pp. 247-259, 2003.

[51] M. Al-Farsi, C. Alasalvar, A. Morris, M. Baron, and F. Shahidi, "Compositional and sensory characteristics of three native sun-dried date (Phoenix dactylifera L.) varieties grown in Oman," Journal of Agricultural and Food Chemistry, vol. 53, no. 19, pp. 7586-7591, 2005.

[52] A. Y. Ali-Mohamed and A. S. H. Khamis, "Mineral ion content of the seeds of six cultivars of Bahraini date palm (Phoenix dactylifera)," Journal of Agricultural and Food Chemistry, vol. 52, no. 21, pp. 6522-6525, 2004.

[53] A. Bijami, F. Rezanejad, H. Oloumi, and H. Mozafari, "Minerals, antioxidant compounds and phenolic profile regarding date palm (Phoenix dactylifera L.) seed development," Scientia Horticulturae, vol. 262, Article ID 109017, 2020.

[54] F. Al Juhaimi, K. Ghafoor, and M. M. Özcan, "Physicochemical properties and mineral contents of seven different date fruit (Phoenix dactylifera L.) varieties growing from Saudi Arabia," Environmental Monitoring and Assessment, vol. 186, no. 4, pp. 2165-2170, 2014.

[55] S. Gharby, H. Harhar, M. Farssi, A. Ait Taleb, D. Guillaume, and A. Laknifli, "Influence of roasting olive fruit on the chemical composition and polycyclic aromatic hydrocarbon content of olive oil," Ocl, vol. 25, no. 3, p. A303, 2018.

[56] A. Zeroual, E. H. Sakar, N. Eloutassi, F. Mahjoubi, M. Chaouch, and A. Chaqroune, "Phytochemical profiling of essential oils isolated using hydrodistillation and microwave methods and characterization of SomeNutrients in origanum compactum benth from central-northern Morocco," Biointerface Research in Applied Chemistry, vol. 11, no. 2, pp. 9358-9371, 2021.

[57] A. Zeroual, E. H. Sakar, N. Eloutassi, F. Mahjoubi, M. Chaouch, and A. Chaqroune, "Wild chamomile [Cladanthus mixtus (L.) chevall.] collected from central-northern Morocco: phytochemical profiling, antioxidant, and antimicrobial activities," Biointerface Research in Applied Chemistry, vol. 11, pp. 11440-11457, 2021.

[58] E. H. Sakar, M. El Yamani, A. Boussakouran et al., "Variability of oil content and its physicochemical traits from the main almond [Prunus dulcis Mill. DA Webb] cultivars grown under contrasting environments in north-eastern Morocco," Biocatalysis and Agricultural Biotechnology, vol. 32, Article ID 101952, 2021. 